\title{
Legal Case Analysis in IS Research: Failures in Employing and Outsourcing for IT Professionals
}

\author{
S. Ang \\ Information Management Research Center \\ Nanyang Business School \\ Nanyang Technological University, Singapore \\ Tel: 657995697 \\ Fax: 657922313 \\ E-mail: asang@ntu.edu.sg \\ A. Endeshaw \\ Division of Business Law \\ Nanyang Technological University, Singapore \\ Tel: 657996242 \\ Fax: 657913697 \\ E-mail: AEndeshaw@ntu.edu.sg
}

\begin{abstract}
In this paper, we introduce readers to the richness of existing legal cases as sources of secondary data for analyzing contemporary issues in the management of information technology. Drawing upon legal research techniques and the principles of typology construction in the social sciences, we describe a method of creating prototypical disputes: synthesizing large masses of qualitative data embedded in past legal cases into summarized descriptions that encapsulate the most commonly found characteristics in those cases. We then demonstrate the development of
\end{abstract}


themes or prototypical disputes on the basis of court decisions on issues arising from employing and outsourcing for IT professionals. We conclude by discussing other domains in the management of IT that may be amenable to the legal case methodology proposed in this study.

\section{INTRODUCTION}

In the 1990s, information technology, with its three components of hardware, software and people, has infiltrated almost every home, business and major industry. IT has become not only a competitive weapon but also a strategic necessity for organizations in the knowledge-based economy. To date, MIS researchers have made significant inroads into understanding how organizations can design and implement information systems to operate their businesses more efficiently and more effectively.

Although we have accumulated significant knowledge about how organizations use MIS, past MIS research presents a very pro-IT success orientation. Researchers tend toward demonstrating IT success, that is, the positive impacts of the use of IT on decision making, productivity or business value. Unfortunately, research that overemphasizes successful use of IT has one major unintended consequence: organizations may unwittingly assume that IT failures are rare and therefore forgo important lessons from failure. Yet, we know from the principles underlying control theory of negative feedback that failures provide equal, if not more diagnostic, information than successes. Studying failures is preventive because it helps firms reduce the probability of failures in the future. Performance failure and implementation errors also provide clear signals that something is amiss and must be changed.

Although failures in IS are important, relatively little research focuses on IT (see exceptions in Lucas 1975; Markus 1983; Lyytinen and Hirschheim 1987; Davis et al. 1992; Ang and Toh 1997). One dominant reason is that organizations often keep silent to avoid any publicity of their failures. They restrict access to information on failures because it can potentially damage their image, reputation, and credibility (Sitkin 1992). Consequently, failed cases are kept hidden in organizational closets. Because of the reluctance of firms to expose their failures and weaknesses, researchers and practitioners alike forgo valuable lessons that can be gleaned from failures.

In this paper, we describe a major source of secondary data - legal cases - that researchers can harness for studying failures in IS (see Lee and Belliars [1992] for their argument for adopting law as a reference discipline for MIS). Unlike the typical case study methodology where researchers intrude into organizations to gather primary and secondary data of the phenomenon of interest, legal case studies offer researchers a very rich and unobtrusive secondary data resource. In fact, legal cases arising from use of IT represent the epitome of failures in one major area, namely computer contracting (other areas of dispute being tort and crime). When disputes arise from IT contracts, organizations will typically try to settle the conflicts out of 
court to preserve the contractual relationship and to avoid unnecessary publicity. However, in cases where informal dispute mechanisms fail, parties will pursue remedies available to them in formal legal litigation (Ang and Beath 1993). Therefore, the legal cases reported often exemplify extreme or heightened circumstances that trigger off conflicts and survive informal private grievance procedures or third-party mediation.

To the best of our knowledge, this paper represents the first effort in IT research to use legal cases to further our knowledge about the use of IT in practice. As with any source of empirical data, there are legitimate concerns about using legal cases. For example, an important question is: what can we learn from legal cases? What could we validly or not validly know or learn about IT from legal cases? What are the boundaries and limits of the knowledge gleaned from legal cases? In this inaugural effort of utilizing legal cases, not all of these issues can be addressed or resolved fully, but some first steps will be taken in that direction.

The paper is divided into two parts. In the first half, we describe the legal case study methodology. This is done by spelling out the sources of, and the techniques for identifying, appropriate legal cases. We also present a method of prototype construction for developing themes characterizing disputes embedded in legal cases.

The second half of the paper illustrates these principles with legal cases on IT failures arising from contracting, employing and/or outsourcing, for IT professionals. We first discuss the unique legal issues that trigger off disputes and then develop constructed types for them. We conclude the article with a discussion of the strengths and weaknesses of the methodology and also other legitimate objections to the methodology that will have to be addressed in future research.

\section{METHODOLOGY OF LEGAL CASE ANALYSIS}

\subsection{Legal Cases as Rich Sources of Data}

Traditional legal research uses cases decided by the courts as primary sources of data. Particularly in the Anglo-American legal system, usually called the common law system, decisions of judges are not only important in themselves (as pronouncements of rights and wrongs relative to specific disputes) but serve as guides for future decisions in similar circumstances. The doctrine of precedents and the authority that decisions of higher courts command over lower ones means that judge-made laws have far more significance than is often realized. The laws in force at any one time are not only those issued by the official law makers (Congress or Parliament), but also those laid down by judges.

The succession of judge-made laws (case authorities) that have become dominant and indispensable components in Anglo-American law has, in turn, created the necessity of accurate reporting of cases from about a century ago. In so far as 
disputants had to prove the law that would support their claims or defenses in courts, possession of records of past cases was both necessary and decisive. In its original meaning, therefore, legal research related to the finding of the law from among the numerous decisions made at the various levels of courts. It took quite a while before this task of finding the law could become relatively easier through the transcription of the judges' decisions and their subsequent collation and reporting on a regular basis. Today, the skills and knowledge required to understand disputes before the courts and to report the decisions (particularly the oral ones) are such that only qualified lawyers undertake this task.

Prior to the availability of IT-based legal databases, cases were reported in thick, paper-based volumes running as serials. The reports continue to be grouped on the basis of the subjects they cover or the geographic area or jurisdiction they originate from. Thus criminal law issues tend to be reported separately from civil law ones. Within civil law too, family cases or commercial disputes appear as distinct reports. On the other hand, as in the United States, cases are reported and organized by States. A more prevalent method is to organize reports by the type of courts which decided the cases; consequently, cases decided in the lower courts are reported in different series than those done by higher ones, such as appeal or supreme courts. It is inevitable that there would be overlaps and some cases find themselves reported in a number of series, partly because of the multiplicity of publishers.

The availability of electronic storage and retrieval of information systems has led to the creation of electronic legal databases. These databases offer lawyers and researchers alike faster and easier access to cases that would otherwise have involved laborious searching. Of the legal databases available, LEXIS services are the most common. One unique feature of LEXIS is that it provides full text reports similar to hard copies available in law libraries (Carrick 1989). The additional advantage of LEXIS is that some unreported cases, that is cases considered not important enough to be included in the regular reports, are also recorded electronically.

\subsection{Searching LEXIS}

LEXIS organizes legal cases hierarchically (Carrick 1989). The first level, called libraries, are followed by subdivisions (sets of files). Legal cases reside primarily in its MEGA library. Each file in the MEGA library contains all available federal and state cases on the LEXIS service. The MEGA files are either circuit-based or statebased. Circuit-based MEGA files combine federal and state cases from federal and state courts within the geographical area defined by the federal circuit. The statebased MEGA files combine cases from the court of the state and the federal district courts as well as cases from the federal circuit for that state.

A search is initiated by typing in keywords (also known in LEXIS as the "search request"). Cases obtained can be browsed either in full text or in KWIC (Key Words In Context). When one browses cases in KWIC, LEXIS extracts the paragraph that contains the keyword so that one can consider its significance in the context of the 
case reported. From the information gleaned from KWIC, one can go on to obtain a paper copy of the case and read the full text.

As with any text-based database, keyword searching does not guarantee that all cases extracted are relevant cases. Keyword searching offers an initial extraction of potential cases of interest. Until intelligent search mechanisms are available, one still has to read and judge the relevance of each case extracted.

\subsection{Creating a Coding Template for Legal Cases}

The most important information residing in legal cases are the facts of the case, the background information of the cases, together with the issues raised in the case, or the nature of the dispute. However, in addition to the facts of the case, there are other salient features of each case that can provide useful background information for legal case analyses. For each legal case, we can code (1) the date in which the case was decided; (2) the state in which the case was heard; (3) the initiating party, that is who started court action (often, the initiating party is the plaintiff; however, in some cases, the initiating party can be an appellant since he will have appealed against a decision of a court in an earlier proceeding); (4) the defendant or responding party whom the initiating party takes action against; (5) the judgment, that is, the decision or ruling of the court in favor of either party; and (6) the rationale - the court's reasons for the judgment. Table 1 presents the coding template listing all the relevant information to be gathered from each legal case.

Table 1 Coding Template for Legal Cases.

\begin{tabular}{|l|l|l|l|l|l|l|l|l|}
\hline $\begin{array}{l}\text { Case } \\
\text { Decided }\end{array}$ & $\begin{array}{l}\text { Date } \\
\text { Decite }\end{array}$ & $\begin{array}{l}\text { Initiating } \\
\text { Party }\end{array}$ & $\begin{array}{l}\text { Responding } \\
\text { Party }\end{array}$ & Facts & $\begin{array}{l}\text { Issues } \\
\text { (Nature of } \\
\text { Disputes) }\end{array}$ & $\begin{array}{l}\text { Judg- } \\
\text { ment }\end{array}$ & Rationale \\
\hline & & & & & & & & \\
\hline & & & & & & & & \\
\hline
\end{tabular}

\subsection{Coding Legal Cases}

With the coding template in place and legal cases searched, one can then proceed to code each case. Depending on the extent of their legal and IT knowledge, coders may have to read up extensively or take a course in computer contracts before coding cases. Prior knowledge in computer contracts is vital to ensure that coders can discern the issues or nature of disputes embedded in each court case.

To ensure inter-rater reliability, at least two coders must be used to code each legal case. Initially, each coder reads and codes the case independently. The coders then come together to compare the results. Inconsistencies are resolved and tacit rules of thumb in the code made explicit. Coders then reiterate the process until they reach 
an acceptable level of inter-rater agreement. Cohen suggests $80 \%$ agreement as computed using the Cohen's Kappa metric as acceptable for nominal scale agreement (Cohen 1960). Cohen's or Krippendorf's (1980) procedures for measuring coder agreement for nominal scales may be adopted. Either procedure measures agreement after random agreement among nominal scales is taken into account.

\subsection{Creating Themes and Developing Constructed Types of Disputes}

Once the coding is completed, the coded information is then used for further analyses. We propose to rely on the principles of typology construction to summarize the massive qualitative information into constructed types. According to Bailey (1994), a constructed type is a description of the most commonly found characteristics in the subject of interest. A constructed type is thus analogous to a measure of central tendency such as a mean. In our context, constructed types represent themes and prototypical disputes that commonly occur in litigious disputes. With the development of an inventory or typology of constructed types, one can better grasp the breath and depth of failures in IT and the most likely outcome of litigious actions.

\section{AN ILLUSTRATIVE EXAMPLE: LEGAL DISPUTES ARISING FROM EMPLOYING AND OUTSOURCING OF IT PROFESSIONALS}

To illustrate the power of legal case analysis, we report here on legal cases arising from employing and outsourcing for IT professionals, a major area of IT disputes driven by severe IT skills shortages coupled with the dramatic infiltration of IT in businesses. We first offer a background on the subject of interest: contracting for services of IT professionals followed by an illustration of how the above methodology can be used to derive themes or prototypical cases that represent failures in contracting for IT professionals.

\subsection{Employing or Outsourcing for Services of IT Professionals}

As a result of the explosive use of IT in all industries, the demand for skilled IT professionals has grown dramatically. Unfortunately, the supply of skilled IT professionals has not kept up with demand (Saxenian 1996). To make matters worse, the pool of competent IT professionals shrinks rapidly by the relentless development of competence-destroying technologies. On average, new IT developments have a useful life span of only about eighteen months. This rapid speed of innovation suggests that whatever skills IT professionals possess today erode very rapidly.

The severe skills shortages coupled with rapid changes in technologies means that organizations face tremendous challenges in developing and managing critical IT operations. Given severe shortages of highly skilled IS workers and rapid erosion of 
IT skills, the organizations continue to wrestle with finding and retaining the critical human resources to manage and use IT effectively within their organizations. The severe shortage also means that competent IT professionals are very marketable and highly mobile. The high interfirm mobility of IT professionals also results in organizations outsourcing for IT services (Slaughter and Ang 1996) rather than merely resorting to traditional employment of IT professionals.

Outsourcing can help balance supply and demand for workers by more efficiently allocating the deployment of workers with scarce skills. As illustrated by Slaughter and Ang (1996, p. 49), if five firms need scarce IS skills, such as client-server programming, and each firm chooses to hire a permanent worker, then five programmers will be required. However, if firms opt for outsourcing, fewer programmers will be required as firms can share the services of the programmers from a common pool.

By outsourcing, organizations move away from the traditional long-term employment arrangement (insourcing) to relatively shorter-term, market-mediated arrangement (outsourcing) with their IS workers. Outsourcing reflects the increasing trend toward downsizing and transforming companies into networked forms by "taking the workers back out" (Pfeffer and Baron 1988).

\subsection{Legal Ramifications in Managing IT Professionals}

Managing IT professionals either by means of traditional insourcing and outsourcing has many legal ramifications. The legal literature identifies three major areas of problems, namely restraint of trade, property rights and the legal status of the professional either as employee or independent contractor (Nimmer 1985; Reed 1990).

Restraint of trade relates to the degree of permitted use of information and skills acquired during the engagement with the employer both during the terms of employment and afterward. Developing software is a highly tacit endeavor. Knowledge about the software developed resides in the heads of software developers and us seldom codified explicitly. Often, the distinction between skills and knowledge acquired on the job, which the professional is allowed to use for his or her own purposes, from the proprietary information, which he or she will have to leave behind for the employer, is blurred. Consequently, employers are keen to protect the information generated with the resources they provide the employee or independent contractor by prohibiting any kind of leakage to competitors, including where the employee sets himself or herself up independently in the line of activity of the employer. Whether the employer will succeed in prohibiting competition and for how long or to what extent have been contested repeatedly. Courts have had to settle these issues by reference to law and public policy. The need to allow skills acquired while under contractual engagements with employers have constantly pushed back the employer's urge to prohibit and constrain contracting parties.

Property rights, usually described as intellectual property rights but not necessarily exclusively them alone, have increasingly become critical in IT employment or 
outsourcing contracts. The determination of who acquires or retains ownership of such products or information generated has been decided by law in terms that employees in principle do not have rights as such. Where outsourcing is involved and the problem of whether the IT professional has rights is raised, the solution has been arrived at by looking at the provision of materials, facilities and other resources for the performance by the IT professional: if such have been supplied by the employer, property rights can be claimed by the employer; where this is not so, they belong to the employee. However, this has only served as a guideline and no final pronouncements have been possible owing to the shifting nature of the relationship.

Other disputes arise from the changes brought about by IT in the relationship between employees and employers. Such are the disputes as to the status of the hired IT professional and the corresponding rights and obligations he or she has vis-à-vis the employer: the obligations of the employer by law such as in paying benefits on behalf of the professional. The traditional legal test of the existence of control or supervision by the employer over the contracting party has increasingly become irrelevant since IT has made it either redundant or redefined the relationship. The compensation that employers have to pay has also become a bone of contention, linked as it is with the status of the professional.

The above represents legal issues that have been discussed and debated at length in computer law books and journal papers. In the next section, we will examine empirically the nature of disputes embedded in past legal cases using the methodology suggested in the first half of this paper.

\section{Searching Relevant Legal Cases on Employing and Outsourcing for IT Professionals}

The first step in the methodology was to find relevant legal cases pertaining to the employment and outsourcing for IT professionals. We gained access to the LEXIS database for the research. In addition to the MEGA library which holds the primary source of all legal cases, LEXIS also contains a special collection on employment issues called the EMPLOYMENT LAW library. This library focuses primarily on public and private section state employment law and contains state and federal cases, fair employment practices, individual employment rights decisions, wage and hour decisions, state and federal codes, state public employee board decisions, employment law treatises, labor arbitration materials, and other relevant employment publications.

In effect, the Employment Law library contains the legal cases pertaining to employment related issues. In the Employment Law library, one can therefore search computer-related employment contracts using strategic keywords such as computer or software. Also, for purposes of this illustrative study, we had restricted our search of the Employment Law cases to the most critical IT related employment cases: cases that appear at the Supreme Courts - the highest and most influential courts in each state. A common search strategy used was to select all cases that contained the key words computer or software and the key word contract within 25 words before or after the former key words. The command used for the LEXIS search was: COURT (SUPREME) AND (COMPUTER! OR SOFTWARE! W/25 CONTRACT!) 
Based on the search strategy, LEXIS identified a total of 249 cases. Of the 249 cases, we narrowed down to 25 cases that have as their central theme disputes arising from the employment and outsourcing of IT professionals. The 25 cases were identified by a careful reading of all the abstracts of the 249 cases and extracting the ones deemed relevant. The other cases were either outrightly irrelevant or tangentially relevant. Extracting 25 cases out of a possible 249 cases seems a very low hit rate (about $10 \%$ ). This suggests we may have to devise a better search strategy than the command we had used in our original LEXIS search.

\section{Coding the Cases}

Two coders were used to code the cases. The coders had working knowledge in IT and were trained by one of the co-authors in legal research methodology. To prepare for the coding process, they also read materials in legal research as well as computer and employment law authorities to ensure that they had sufficient background knowledge to understand the common themes and disputes arising out of computer contracting.

As a first task, the coders photocopied the 25 cases from hard copies of case report found in the Law library. Next, they read the cases independently, and coded information based on the coding template presented in Table 1. The result of the coding is shown in Appendices 1 and 2. Of the elements in the template, the one of greatest subjective contention is the issue or the nature of dispute. Once they had coded each case, they compared notes, discussed the cases, and arrived at a consensus on the facts, issues, judgments, and rationale. To further ensure the validity of their interpretation, one of the co-researchers, who is the computer legal expert, read through the cases and verified their coding.

\section{Developing Themes or Constructed Types}

Following formal legal case analysis techniques, the first step in arriving at the themes was to sift the facts and issues in the 25 decided cases and summarize them. This is shown in Appendices 1 and 2, where all the relevant information for each case are entered. The second step involved establishing the recurrence of disputes. This was done by going through the section under issues and determining what areas of law was in contention. Depending on the type of dispute, a tally was made of the overall total for each category. This is shown in Table 2.

As shown in Table 2, the major type of dispute concerns restraint of trade. Typically an employer would have an employee agree to a term in the contract of employment which prohibits the employee, during the period of employment or a few years (one to two) afterward, from engaging in any business (similar to the employer's) that might compete against the employer. Usually this takes the form of noncompetition pure and simple (with indications as to the extent of prohibition geographic scope as well as duration of time and type of business). Often, the employee may be precluded from using trade secrets or such other information as was particular to the type of business of the employer. Consequently, restraint of trade meshes in with confidentiality clauses. 
Table 2 Recurrence of Types of Disputes in the Selected 25 Cases.

\begin{tabular}{|l|l|l|}
\hline Types of Disputes & Recurrence & Cases \\
\hline Restraint of trade & 8 & $1,2,6,9,16,19,23,24$, \\
\hline Status of IT personnel & 6 & $5,7,10,11,12,21$, \\
\hline Confidentiality & 5 & $6,9,19,20,24$ \\
\hline Procedure & 5 & $4,14,15,17,22$, \\
\hline Ownership & 3 & $3,13,20$ \\
\hline Compensation & 3 & $8,15,25$, \\
\hline Fiduciary duty & 1 & 18, \\
\hline
\end{tabular}

Disputes on restraint of trade arise chiefly where (a) the interests to be protected by the employer have not been clearly spelled out; (b) the clauses are too broad and do not stand the test of reasonableness that is used by the courts to determine whether such clauses are valid; (c) the interests of the employee who seeks to use the information and skill acquired in the course of employment and that of the employer who does not to wish to be placed at a disadvantage as a result are in conflict. Courts are likely to give the benefit of the doubt to the employee.

The second major type of dispute relates to the status of the employee. The use of multiple forms of contracting (written, oral, or both written and oral) as well as variations in the degree of control exercised by the employer have produced disputes. The first kind of dispute is as to whether the written contract of employment is conclusive. The second is regarding the relationship between the employer and persons it hires supposedly as independent contractors but restricts in the manner of their work and dealings with clients of the employer. Although these are standard issues in contracts of employment, the changes occasioned by IT in the nature of employer-employee relations (particularly in lessening of control by the former) may have served to rekindle them.

The third most important type of dispute concerns the employer's quest to enforce confidentiality clauses. Usually, this takes the form of an employer seeking to prevent an employee, whether during employment or on termination, using the information made available to him or her by the employer for another employer or for his or her own benefit. The question that would need to be resolved is the confidentiality of the information; that is, whether the information was not publicly available or that it was produced (compiled, invented or otherwise generated) in the employer's business. Courts would refrain from enforcing the obligation of an employee in this regard if they find that the information was widely known or not patentable. At times, the employer's effort to protect its "trade secret" may be similar to, and overlap with, restraining an ex-employee from competing against it. 
Procedural issues figure as the fourth important type. These range from preliminary issues as to whether the courts have jurisdiction to receive the cases, the use and type of evidence allowed to prove contracts or claim compensation, the forms of dispute settlement the parties may have agreed to in the contract and the time span within which action can be brought in courts. While these issues may not relate to the substance of the dispute at hand, they would often affect the outcome, if and when the dispute is decided by the courts. The strength of the parties on the underlying dispute may not necessarily determine the court's final ruling where the party concerned did not observe the correct procedural steps and proves it to the court's satisfaction.

Ownership of information generated by employees during employment (whether at the work place or outside) and the compensation they would expect from their work (salaries or commissions) are the last two types of disputes. The use of the employer's facilities and time has generally been the yardstick to determine if the employer can claim proprietorship over the information generated by the employee. On the other hand, the level of compensation due to the employee has been difficult to assess partly because of the combination of oral and written forms in the contract, and partly because of the fluctuating nature of commission.

\section{STRENGTHS AND WEAKNESSES OF THE METHODOLOGY}

Since in this paper we are chiefly concerned with introducing and illustrating a methodology, we shall presently take up a discussion of strengths and weaknesses as well as the major objections that may be raised against the methodology. These determine when the use of legal cases is the preferred approach and when it is not.

\subsection{Strengths}

The chief strength of the methodology is the use of very rich, and relatively untapped, legal cases as secondary data. Cases are written in considerable detail by case reporters. Whereas traditional case studies rely primarily on interviews or questionnaires that intrude as foreign elements into the social settings (Webb et al. 1966), legal cases are unobtrusive, do not require cooperation of firms, and they do not themselves contaminate the responses. We have discussed earlier the reluctance of companies to share their failure stories with researchers for fear of loss of reputation and credibility. Legal cases offer an excellent source of data to plug a hole in our existing research that grossly under-rated failures. Legal cases open windows for us to peer into the events that lead to contractual disputes that firms were not able to resolve through informal dispute resolution mechanisms.

The second strength of the methodology is the developing of constructed types from legal cases. Constructed types enable researchers to synthesize large numbers of legal cases which may differ in context but share a number of distinctive features 
that characterize the legal issue in dispute. Constructed types reduce complexity and achieve parsimony. It allows one to identify both similarities among cases as well as differentiate between them. A full typology of constructed types of issues arising from legal disputes is also an excellent inventory tool for researchers and practitioners. It allows one to locate and position any problem that arises and know at all times what types are available for analysis.

The third strength of the methodology is the breadth of application. One can use the methodology to describe and understand potential causes of failures and disputes in computer contracting. With the heightened awareness and use of outsourcing in the management of IS, a thorough understanding and appreciation of failures that lead to legal disputes can potentially avert costly litigation and disruption of business operations. We have demonstrated the use of the methodology to examine disputes arising from employing and outsourcing for IT professionals. The methodology may be used to understand other IT-related issues such as disputes in software development outsourcing (e.g., see Ang and Toh 1996), disputes in facilities management outsourcing, personal rights to privacy, intellectual property pertaining to electronic sources, etc.

\subsection{Weaknesses}

Like any method, the methodology of developing constructed types from legal cases has certain weaknesses. First, the methodology calls for good grounding and extensive knowledge in law and IT. Both disciplines have considerably high knowledge barriers, each with a very idiosyncratic set of jargon. The greatest challenge facing researchers is overcoming the high knowledge barriers, particularly the technical jargon embedded in both the fields of law and IT. Unfortunately, relatively few researchers possess competencies in the two areas. IT researchers are typically not trained in law and, similarly, few law researchers have sufficient technical grounding in IT to appreciate and understand the complexities of managing IT. A solution to the problem is for sustained, cross-disciplinary collaboration between IT and legal researchers. First, collaborators must possess declarative knowledge in the fundamental concepts in both law and IT. This knowledge is best learned through formal education: basic courses in business law and information technology. Next, they must also have the motivation and willingness to invest in cross-training and cross-educating each other on the idiosyncratic knowledge of each other's domains. Through the collaborative effort, birds of different feathers learn to flock together.

Second, the ability to develop constructed types is predicated on the nature of the legal disputes. If there are sufficient numbers of cases with similar characteristics, then constructed types make sense. On the contrary, if cases have too few common threads, then developing constructed types will be meaningless as there will be as many constructed types as individual cases. 
Third, there are limitations inherent to the sources. The collection of cases depends very much on what is available in reports. It would probably never be possible to have access to all the relevant cases which were disputed by parties before the courts. A large percentage would be settled out of court either because the parties did not consider that going to court would be advisable, financially worth their while or of any importance. Cases which might involve trade secrets or elements of businesses that have critical importance to the operations of those businesses are usually not allowed to develop into full blown disputes enjoying the glare of publicity that would inevitably follow them. Whether as plaintiffs or defendants, companies which do not wish this to happen to them will proceed to resolve their disputes through arbitration or private settlements.

\subsection{Major Objections to the Methodology}

Apart from the weaknesses iterated above, there are certain legitimate objections that can be raised against the methodology presented. These relate, but are not by any means confined, to the extent to which cases represent reality and incorporate relevant facts, biases introduced into cases by the opposite parties' perceptions, sanitization of cases because of removal by the courts in their decision of the political and social context, the time lag between disputes and judgment, the representative nature of LEXIS records and the sufficiency of the number of cases selected through it for research. Others which might introduce a potentially significant source of noise into the analysis are problems in the coding procedure, the value of generalization of research in IT-related cases where jurisdictional limitations matter, the indeterminable nature of what is or is not reported, and the process of filtering of facts that judges may be felt to undertake in formulating legal rules. We will attempt to examine each of these possible objections below.

All cases start with a complaint, called a claim, by a plaintiff who attempts to state as fully as possible the grounds for such a claim - all allegations and facts that the plaintiff views to be supporting it. The party responding to the claim will in turn either deny the alleged legal infraction, submit its own contrary claims or accept the plaintiff's allegations partly or wholly. Both parties must at the same time set out the evidence (documents or witnesses) they rely upon. It will then be up to the judge(s) to decide whose claims have been borne out by the presented evidence. Judgments so rendered are expected to be based on the proven facts and the arguments presented by the parties. This does not change whether the verdict becomes favorable to the plaintiff or the defendant or that it is written or issued orally - such being a frequent practice, particularly in the trial courts (Stone and Wells 1991).

It follows from this that, normally, a legal case consists of all the relevant data or facts that pertain to a specific dispute or disputes. Any failure in that regard does not prevent judgment from being given as each judgment is commensurate with the extent of proven facts laid before the courts. While all the reports of judgments (when made) may not necessarily record all the facts of a case, the more credible and authoritative 
ones produced by trained lawyers in the employ of long established publishing houses routinely incorporate all the relevant or (in legal parlance) material facts that were recognized to be such by the judges in the particular case. Sometimes too, the reporters seek the assistance of the courts (either the judges personally or the archivists) to verify the accuracy of their reports. This is particularly so in England.

Consequently, legal cases properly reported or published in the major series do reproduce the relevant facts in each dispute. Those facts that might be omitted for lack of space and in consideration of the great number of cases that have to be reported regularly on a daily basis would in the general course of things be those that are nonmaterial or without consequence to the legal dispute. The summaries made in Appendix 2 of the facts are hence those most important relative to the issues to be resolved by the courts in each case. The brevity of the facts is not because more could not have been said of the parties or the circumstances of the dispute but that such lay at the bottom of the disputes and all else contributed nothing or very little to the decisions of the courts.

The fact that legal disputes are handled by two opposed parties with partisan views of what is right or wrong might suggest that the judgment when given would suffer from a bias. Yet such a view ignores the fundamental role of the conduct of a trial by judges (sometimes supported by the jury): the establishment to the extent possible of objective facts or data supported by incontrovertible evidence. The standard of evidence required of the contestants is such that neither sides' bias could possibly be a basis for any decision no matter the strength of argument it is presented under. In the end, whatever purposes the data so obtained may be put to, there can be no doubt that they provide the background (in a distilled form) for the decision reached by the judges. The use of those data in the decisions could of course be possible for all types of studies. However, our contention is that they can be amenable to IS research, as demonstrated in the particular example of outsourcing of IS professionals. The absence from the judgment of other data, political or otherwise, which might give a different complexion to the reported case (thereby arguably "sanitizing" it) does not prevent us from using the case for our projected purpose. What it means is only that other studies may have to examine the extent of use of the facts given in case reports for their specific objectives. As far as IS research is concerned, it is our finding that the facts as given in the reports are sufficient and do not suffer from any distillation or sanitization that might otherwise reduce their utility.

Viewed differently, too, the existence of bias is true for standard case methodology as well, where the ethnographic ethos of interpretivism is central (Geertz 1983; Van Maanen 1988). As Stake (1994) elegantly puts it, what we perceive, study, and record in any case study are subjective representations and choices :

One cannot know at the outset (of conducting a case study) what the issues, the perceptions, the theory will be. Case researchers enter the scene expecting, even knowing, that certain events, problems, relationships will be important, yet discover that some actually are of little consequence. Case content evolves in the act of writing itself.

Even though committed to empathy and multiple realities, it is the researcher who decides what is the case's own story, or at least what of the 
case's own story he or she will report. More will be pursued than was volunteered. Less will be reported than was learned. Even though the competent researcher will be guided by what the case may indicate is most important, even though patrons and other researchers will advise, what is necessary for an understanding of the case will be decided by the research. It may be the case's own story, but it is the researcher's dressing of the case's own story. This is not to dismiss the aim of finding the story that best represents the case, but to remind that the criteria of representation ultimately are decided by the researcher. [Stake 1994, p. 240; emphasis added]

Therefore, the point about whether legal cases are biased in representing reality does not appear to be a specific deficiency, even were it provable.

Will the variation between the date of filing (presentation) and that of the decision of cases matter? Undoubtedly, the intervening periods after the presentation or filing of a claim before a court may matter if similar cases have appeared elsewhere and decisions have been passed on the pending issues. Decisions by higher courts in the same jurisdiction will have a direct impact as they become binding immediately; other court decisions may be influential and persuasive, depending on their merit. In any case, the value for this study of the decision in any reported case will not become any less simply because time will have transpired between the date of filing and of the decision.

On the other hand, it is true that the dates of original disputes are important for IS research. It is also true that such can be found for all cases, whether they are at appeal levels or before the highest courts. The illustrative examples used in the paper have had to be limited to the Supreme Courts of states not because the value of such an information was ignored but because it would require more time and labor to dig through all the relevant decisions at the lower levels and to weigh the jurisdictional/state legal variations that might have had an impact in each case. The conscious decision to avoid these two elements was taken in order to make the presentation of the methodology simpler and limit the diversionary elements that might bog the reader's mind in unnecessary detail at this inaugural stage. It would be at the stage of full study of the different facets of outsourcing that a comprehensive concern for all the aspects would be necessary.

Otherwise, the illustrative use we have made of cases brought before the Supreme Courts does not limit the pertinent issues to be raised in or the relevance to IS research of such cases. Indeed, the differences between cases in Supreme Courts and those in lower courts in most cases relate to the complexity of issues involved and either the degree of dissatisfaction of the parties with the judgment rendered or their deep pockets. Thus if the type and number of cases appearing before the Supreme Courts can tell us anything distinct about them, it will not be about the nature of the cases. Cases decided at lower courts but not presented before the Supreme Courts would not necessarily have lacked the merit required of them to do so, although some might not be able to make it for procedural reasons. (It is the practice of courts that appeals are allowed on legal grounds and that every appeal beyond the first level must prove the existence of those grounds.) 
The objection as to the insufficiency in the number of reported cases expresses what is but widely known. It is readily acknowledged that even with the 4 million or. so cases reported up to now since reporting started in 1789 (at appellate levels) and since 1817 (at the US Supreme Court level) and the current annual of 13,000 cases from about 600 courts (Jacobstein, Mersky and Dunn 1994, at 23), no complete reporting of all cases has been possible, for one reason or another. It is therefore obvious that LEXIS cannot be all-inclusive while even the hard-back reports of cases that it is based on are not. Neither do we claim that the legal cases we have investigated represent all disputes arising from employment and outsourcing IT personnel. In fact, we have indicated in our introduction that organizations typically try to preserve their contractual relationship and avoid publicity by resorting to informal dispute mechanisms. It is only when all informal means fail that the hard legal court remedy is pursued.

Even then, the number of cases presented for the illustration is an absolute one. No attempt was made to select any number from a larger pool. The process used in determining which were relevant and which not was an open-ended one, without any need to discriminate between cases. Therefore whether or not 25 cases were a low or high number could not arise. Any desire to enlarge the number could lead only to the inclusion of lower court decisions because the 25 arrived at are the maximum possible, at the supreme court levels, using the existing resources of LEXIS.

We recognize that the coding procedure can be enhanced. ${ }^{1}$ To avoid the influence of one coder over another, a sequential adjustment procedure may be adopted. In this procedure, coders first code independently a relatively small sample of cases (e.g., ten or twelve). They then compare results and resolve differences, evolving standard rules of thumb for coding subsequent cases. They then independently content code another small sample of cases and results are compared and differences resolved. This process repeats until a satisfying level of agreement is reached among the coders and the coding stabilizes. Only then can subsequent sample cases be coded independently and used for further data analysis. Typically for a novice, a case takes between two to three hours to code. However, once one becomes familiar with the specialized legal vocabulary, and genre of legal case reports, a case takes between fifteen to thirty minutes to code.

\section{REFERENCES}

Ang, S., and Beath, C. M. (1993). "Hierarchical Elements in Software Contracts." Journal of Organizational Computing, Volume 3, Number 3, pp. 329-362.

Ang, S., and Toh, S. K. (1997). Failure in Software Outsourcing." In M. Lacity and L. Willcocks (Editors), Outsourcing: Theory and Practice. New York: Oxford University Press, forthcoming.

\footnotetext{
${ }^{1}$ We are grateful to an anonymous reviewer for the suggestion of this sequential adjustment procedure.
} 
Bailey, K. D. (1994). Typologies and Taxonomies: An Introduction to Classification Techniques. Thousand Oaks, California: Sage University Paper series on Quantitative Applications in the Social Sciences, 07-102.

Carrick, K. M. (1989). LEXIS: A Legal Research Manual. Dayton, Ohio: Mead Data Central.

Cohen, J. (1960). “A Coefficient of Agreement for Nominal Scales." Educational and Psychological Measurement, Volume 20, Number 1, pp. 37-46.

Davis, G. B.; Lee, A. S.; Nickles, K. R.; Chatterjee, S.; Hartung, R.; and Wu, Y. (1992). "Diagnosis of an Information Systems Failure: A Framework and Interpretive Process." Information \& Management, Volume 23, pp. 293-318.

Geertz, C. (1983). Local Knowledge. New York: Basic Books.

Jacobstein, J. M.; Mersky, R. M.; and Dunn, D. J. (1994). Fundamentals of Legal Research, Sixth Edition. Westbury, New York: The Foundation Press, Inc.

Krippendorf, K. (1980). Content Analysis: An Introduction to its Methodology. Newbury Park, California: Sage Publications.

Lee, A. S., and Belliars, K. (1992). "Law as a Reference Discipline for MIS." Working Paper, Management Information Systems Research Center, University of Minnesota, Minneapolis.

Lucas, H. (1975). Why Information Systems Fail. New York: Columbia University Press.

Lyytinen, K., and Hirschheim, R. (1987). "Information Systems Failures: A Survey and Classification of the Empirical Literature." In P. I. Zorkoczy (Editor), Oxford Surveys in Information Technology, Volume 4. New York: Oxford University Press, pp. 257-309.

Markus, M. L. (1983). "Power, Politics, and MIS Implementation." Communications of the ACM, Volume 26, Number 6, pp. 430-444.

Nimmer, R. T. (1985). The Law of Computer Technology. Boston: Warren, Gorham $\&$ Lamont.

Pfeffer, J., and Baron, J. (1988). "Taking the Workers Back Out: Recent Trends in the Structuring of Employment." In B. M. Staw and L. L. Cummings (Editors), Research in Organizational Behavior, Volume 10. Greenwich, Connecticut: JAI Press, pp. 257-303.

Reed, C. (1990). Computer Law. London: Blackstone Press Limited.

Saxenian, A. (1996). "Beyond Boundaries: Open Labor Markets and Learning in Silicon Valley." In M. B. Arthur, and D. M. Rousseau (Editors), The Boundaryless Careers. New York: Oxford University Press, pp. 23-39.

Sitkin, S. B. (1992). "Learning Through Failure: The Strategy of Small Losses." In B. M. Staw and L. L. Cummings (Editors), Research in Organizational Behavior, Volume 14. Greenwich, Connecticut: JAI Press, pp. 231-266.

Slaughter, S. A., and Ang, S. (1996). "Employment Outsourcing in Information Systems." Communications of the ACM, Volume 39, Number 7, pp. 47-54. 
Stake, R. E. (1994). “Case Studies.” In N. K. Denzin, and Y. S. Lincoln (Editors), Handbook of Qualitative Research, Thousand Oaks, California: Sage Publications, pp. 236-247.

Stone, J., and Wells, W. A. N. (1991). Evidence: Its History and Policies. Woburn, Massachusetts: Butterworth-Heinemann.

Van Maanen, J. (1988). Tales of the Field. Chicago: University of Chicago Press. Webb, E. J.; Campbell, D. T.; Schwartz, R. D.; and Sechrest, L. (1966). Unobtrusive Measures: Nonreactive Research in the Social Sciences. Chicago: Rand McNally \& Company.

\section{BIOGRAPHY}

Soon Ang is Head of the Division of Human Resource and Quality Management. She specializes in human resources and IT management. She graduated from the University of Minnesota in MIS with supporting fields in organizational psychology and strategic management. Soon Ang currently serves as an Associate Editor for Information Systems Research and a Consulting Editor for Journal of MIS Education. Her current research interests are in information systems outsourcing, managing hi-tech professionals, and cross-cultural management.

Assafa Endeshaw (LLB LLM PhD) is a lecturer in law at the Nanyang Business School. He specializes in intellectual property, information technology and transfer of technology laws as well as in international trade and franchising. He was previously a legal attorney and advisor in government departments and a consultant in a law firm in Ethiopia. Dr Endeshaw has authored Intellectual Property in China: The Roots of the Problem of Enforcement and Intellectual Property Policy for Non-Industrial Countries. He is also a regular contributor to the "Information Technology" column of The Singapore Law Gazette. 


\begin{tabular}{|c|c|c|c|c|c|c|}
\hline 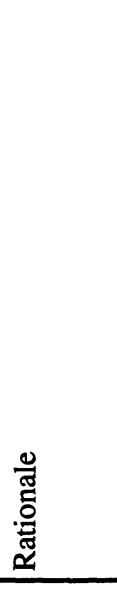 & 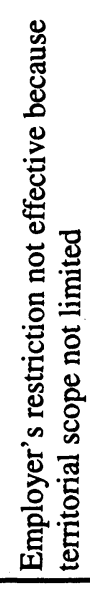 & 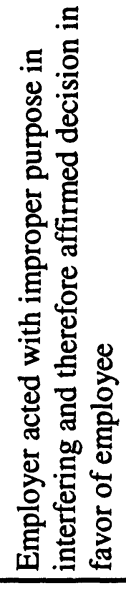 & 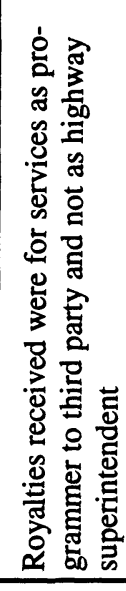 & 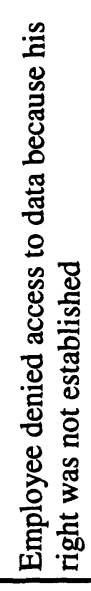 & 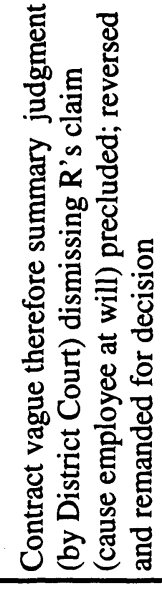 & 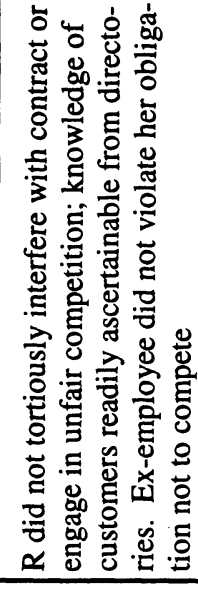 \\
\hline 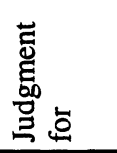 & 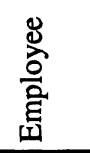 & 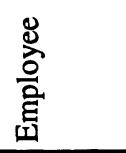 & 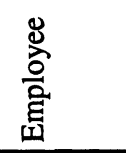 & 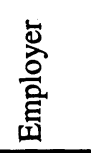 & 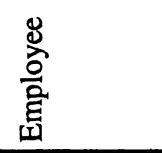 & 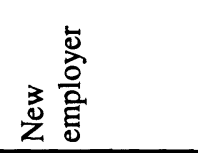 \\
\hline 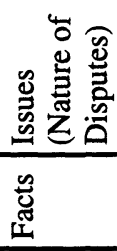 & 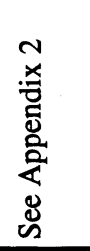 & 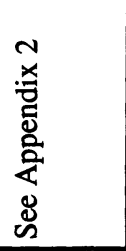 & 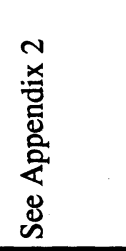 & 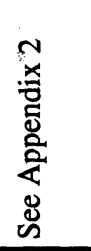 & 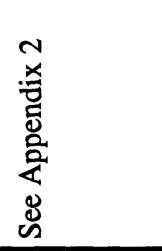 & 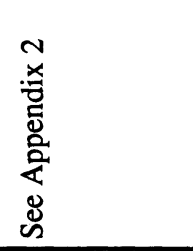 \\
\hline 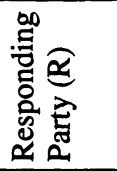 & 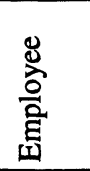 & 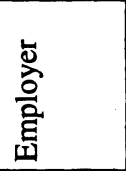 & 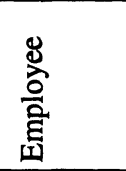 & 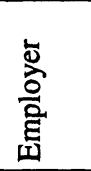 & 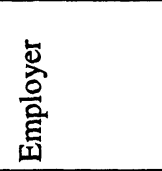 & 竞 \\
\hline 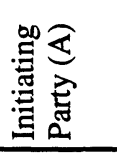 & 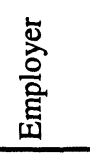 & 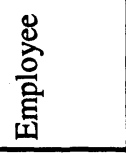 & 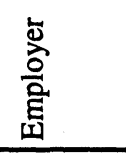 & 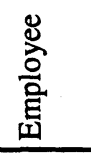 & 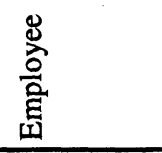 & $\begin{array}{l}\text { 产总 } \\
\text { 离产 }\end{array}$ \\
\hline 总 & 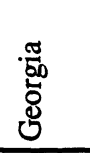 & 殷 & $\begin{array}{l}\text { \% } \\
\text { 今. } \\
\text { 今 } \\
\dot{\omega}\end{array}$ & 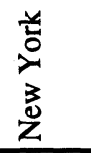 & 銶 & 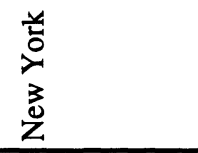 \\
\hline 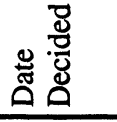 & 莺 & 莺 & g & $\stackrel{\varrho}{g}$ & $\stackrel{\approx}{\Omega}$ & \\
\hline 惫 \# & - & & $\pi$ & 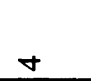 & $n$ & \\
\hline
\end{tabular}




\begin{tabular}{|c|c|c|c|c|c|c|c|}
\hline 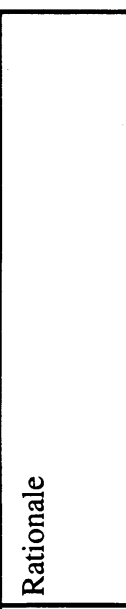 & 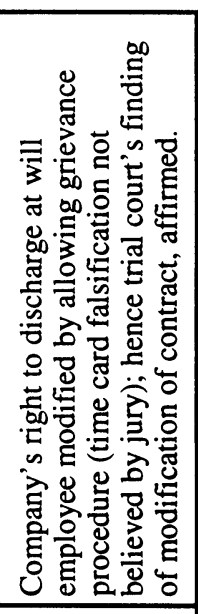 & 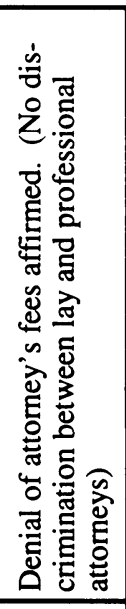 & 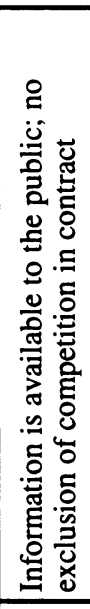 & 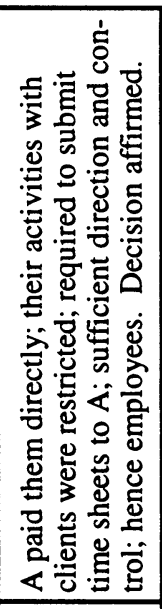 & 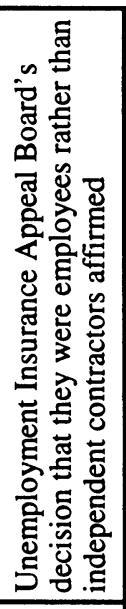 & 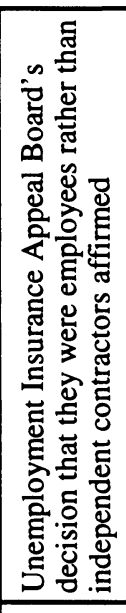 & 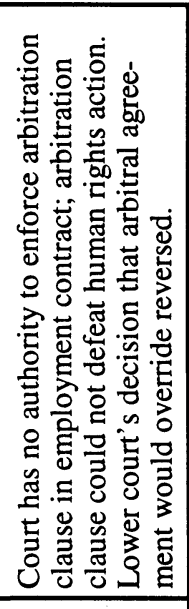 \\
\hline $\begin{array}{l}\text { 志 } \\
\text { 总 } \\
\text { 总 } \\
\end{array}$ & 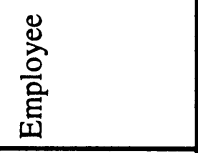 & 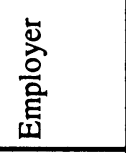 & 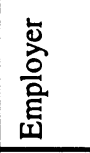 & 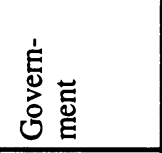 & 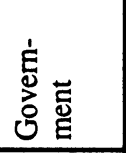 & 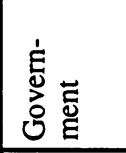 & 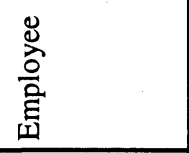 \\
\hline 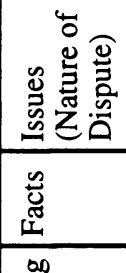 & 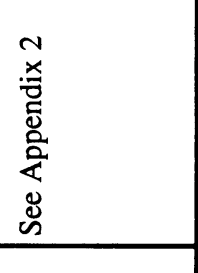 & 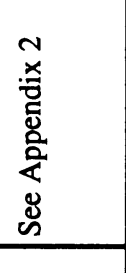 & 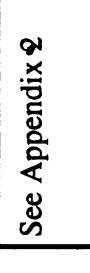 & 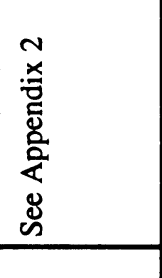 & 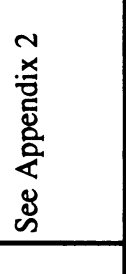 & 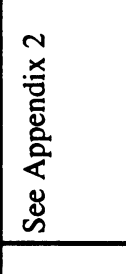 & 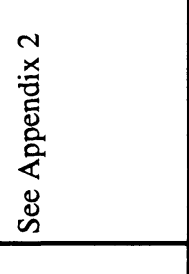 \\
\hline 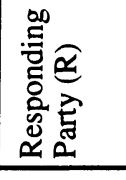 & 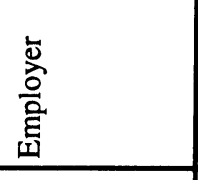 & 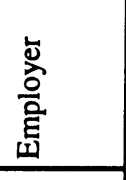 & $\begin{array}{l}\text { \$े } \\
\text { o. } \\
\text { 言 } \\
\end{array}$ & 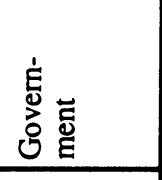 & 离 & 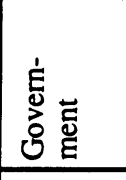 & 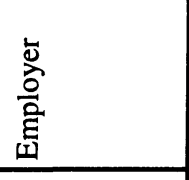 \\
\hline 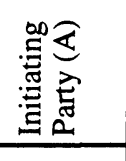 & 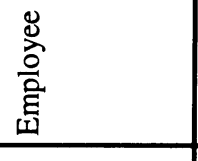 & 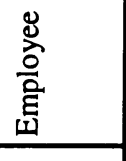 & 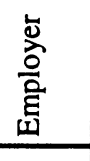 & 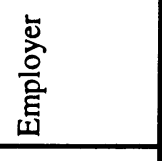 & 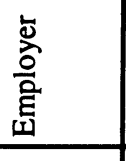 & 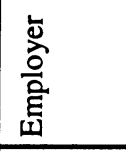 & 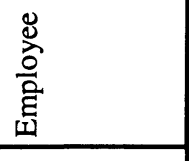 \\
\hline 恚 & 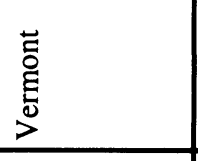 & 胥 & 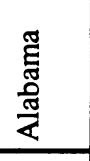 & 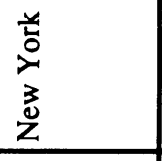 & 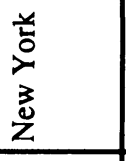 & 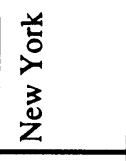 & 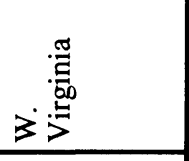 \\
\hline 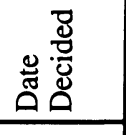 & ळ & & 2 & $\bar{\sigma}$ & 号 & $\stackrel{2}{2}$ & \& \\
\hline$\mho^{\varpi} \#$ & & $\infty$ & $a$ & $=$ & $\Xi$ & $\simeq$ & 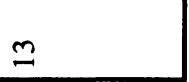 \\
\hline
\end{tabular}




\begin{tabular}{|c|c|c|c|c|c|c|c|}
\hline 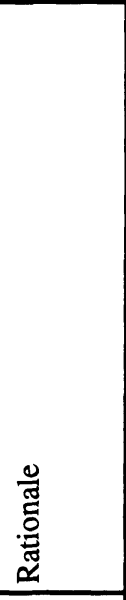 & 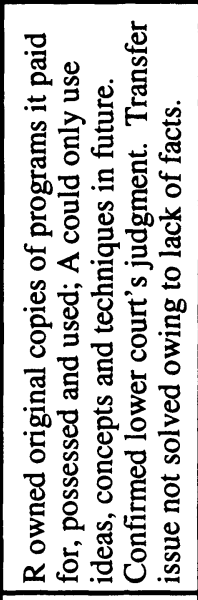 & 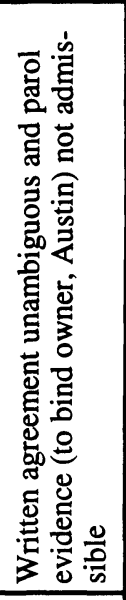 & 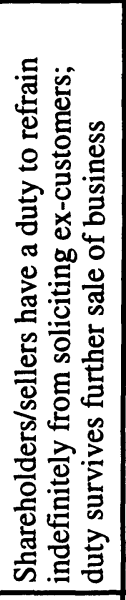 & 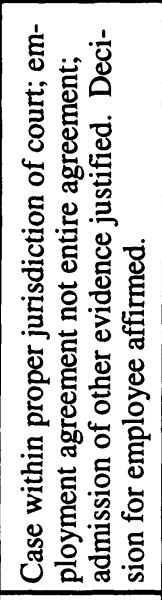 & 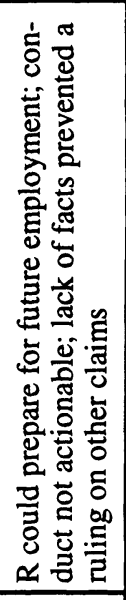 & 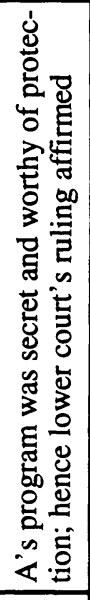 & 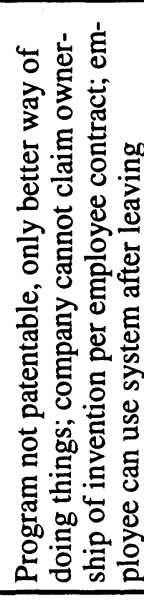 \\
\hline 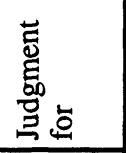 & 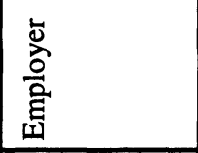 & 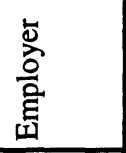 & $\begin{array}{l}\text { 总 } \\
\text { 总 } \\
\text { 量 }\end{array}$ & 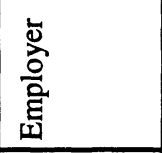 & 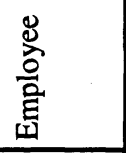 & 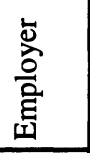 & 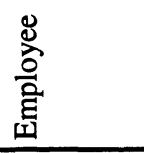 \\
\hline 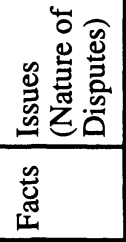 & 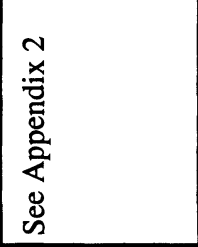 & 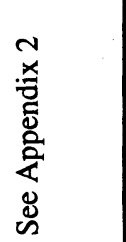 & 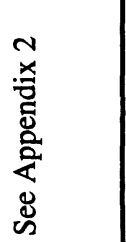 & 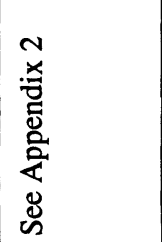 & 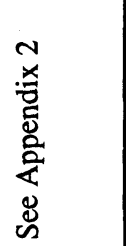 & 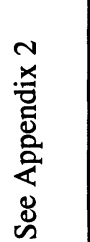 & 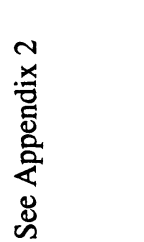 \\
\hline 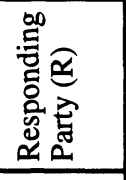 & 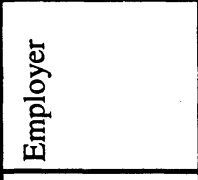 & 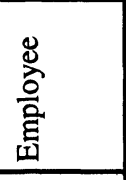 & 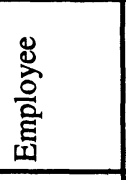 & 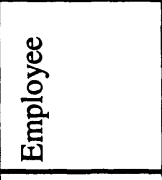 & 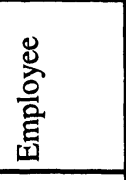 & $\begin{array}{l}\stackrel{8}{0} \\
\text { o. } \\
\text { 密 }\end{array}$ & 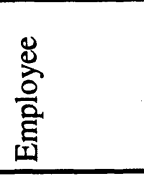 \\
\hline 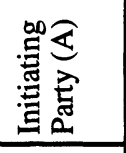 & 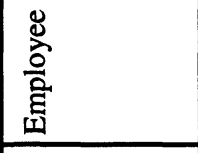 & $\begin{array}{l}\text { 蒿 } \\
\text { 亮 } \\
\text { 息 }\end{array}$ & 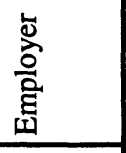 & $\begin{array}{l}\text { 岕 } \\
\text { 总 } \\
\text { 竞 } \\
\end{array}$ & $\begin{array}{l}\text { 嵓 } \\
\text { 亮 } \\
\text { 息 }\end{array}$ & 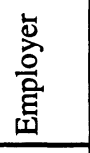 & $\begin{array}{l}\text { 志 } \\
\text { 亮 } \\
\text { 息 }\end{array}$ \\
\hline 产 & 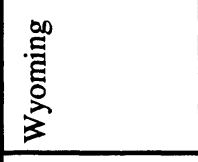 & $\begin{array}{l}\text { 㳫 } \\
\text { 蛋 } \\
\end{array}$ & 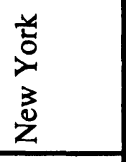 & 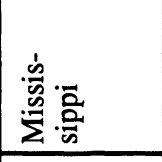 & 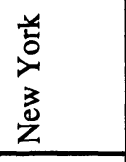 & 㦛 & 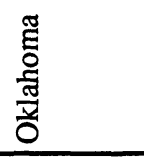 \\
\hline 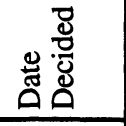 & $\stackrel{\infty}{\stackrel{\infty}{9}}$ & $\stackrel{\infty}{\circ}$ & $\stackrel{\circ}{\stackrel{\circ}{9}}$ & $\stackrel{\infty}{\stackrel{\infty}{\Omega}}$ & $\stackrel{\mathscr{\varrho}}{=}$ & $\stackrel{\infty}{\varrho}$ & $\stackrel{\circ}{\stackrel{\circ}{9}}$ \\
\hline 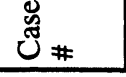 & \pm & $\underline{\simeq}$ & $\underline{0}$ & $\Xi$ & $\stackrel{\infty}{-}$ & 9 & तి \\
\hline
\end{tabular}




\begin{tabular}{|c|c|c|c|c|}
\hline 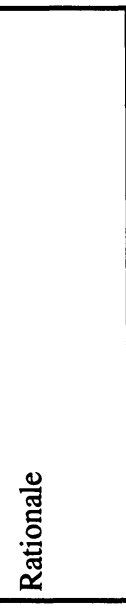 & 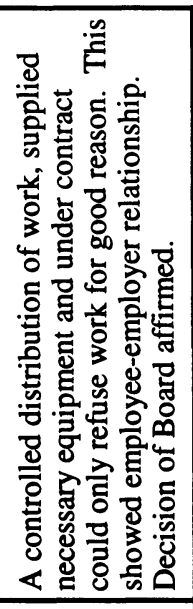 & 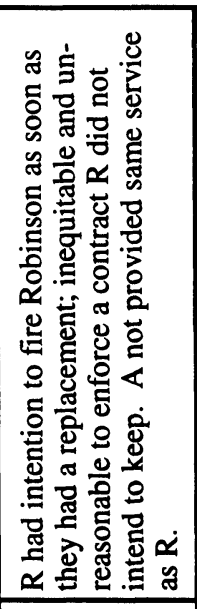 & 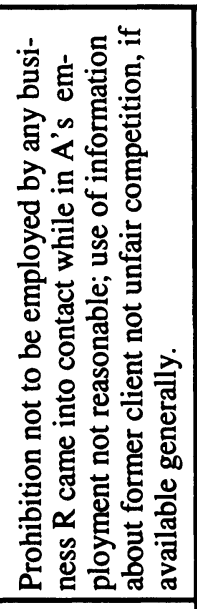 & 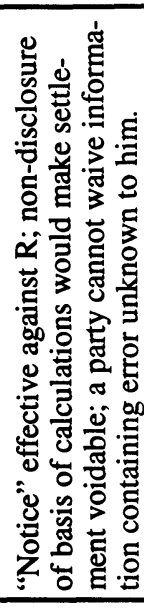 \\
\hline 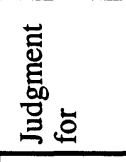 & 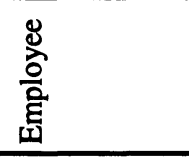 & 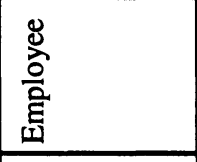 & 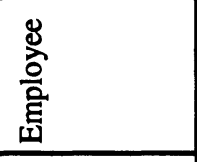 & 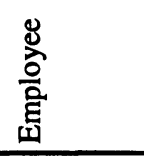 \\
\hline 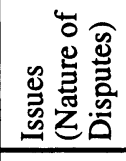 & 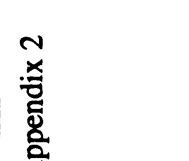 & 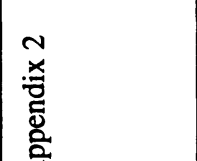 & 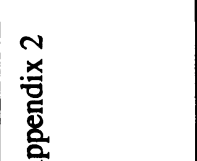 & 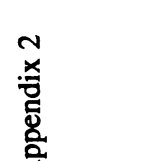 \\
\hline 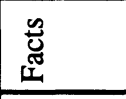 & 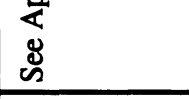 & 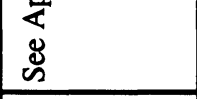 & 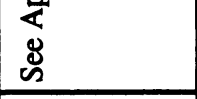 & 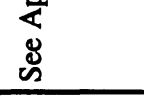 \\
\hline 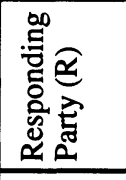 & 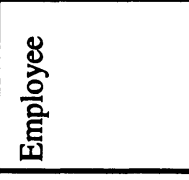 & 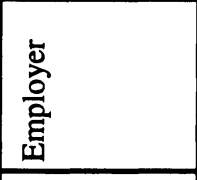 & & $\begin{array}{l}\text { 总 } \\
\text { 竞 } \\
\text { 焉 }\end{array}$ \\
\hline 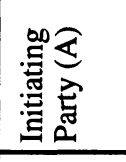 & 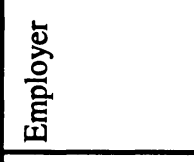 & 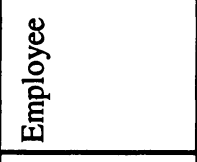 & 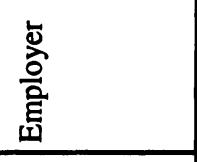 & 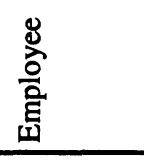 \\
\hline 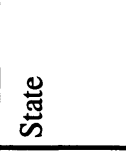 & 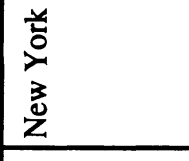 & 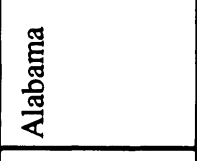 & 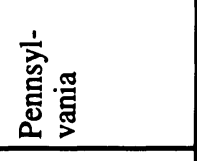 & 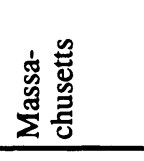 \\
\hline 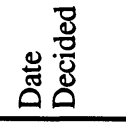 & $\stackrel{\circ}{\stackrel{\circ}{9}}$ & $\stackrel{\Sigma}{\underline{\sigma}}$ & $\stackrel{5}{2}$ & $\Xi$ \\
\hline$\stackrel{g}{a} \#$ & $\bar{\sim}$ & $\tilde{\lambda}$ & d & $\pi$ \\
\hline
\end{tabular}




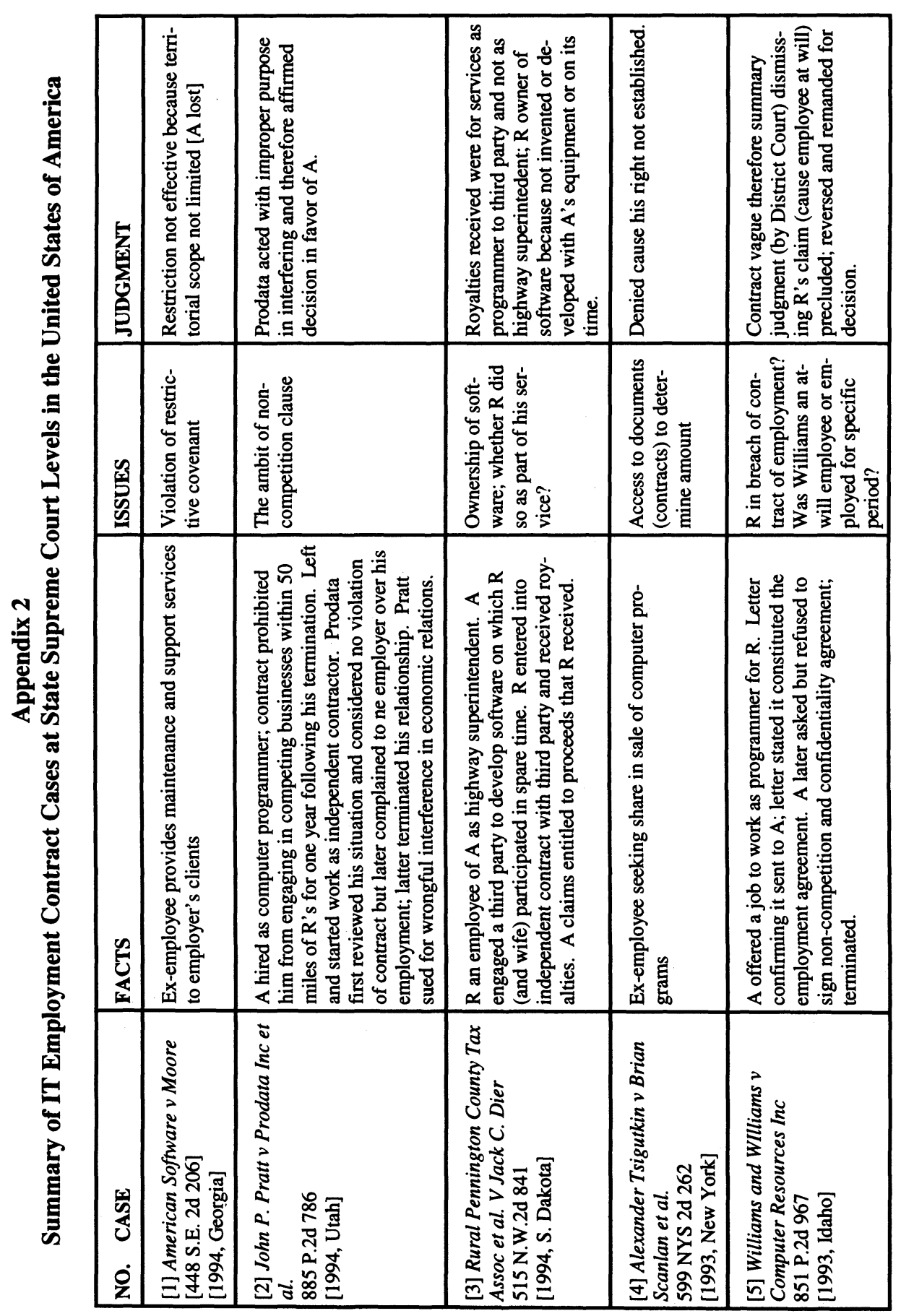




\begin{tabular}{|c|c|c|c|c|c|}
\hline 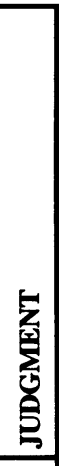 & 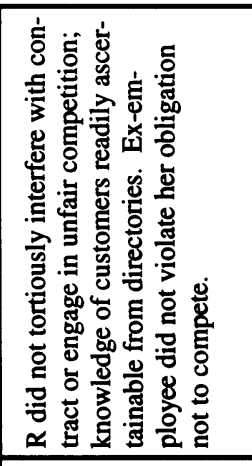 & 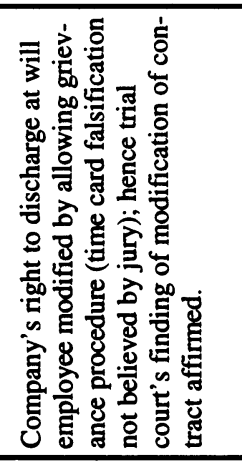 & 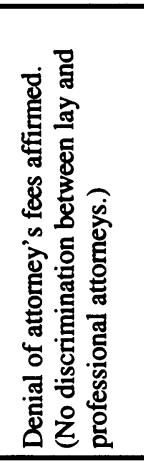 & 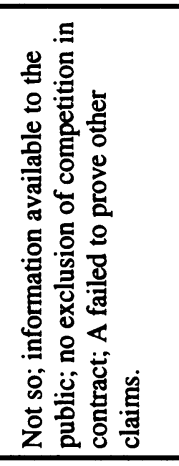 & 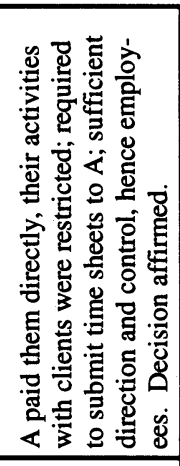 \\
\hline 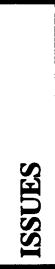 & 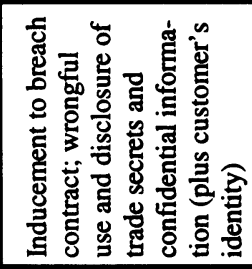 & 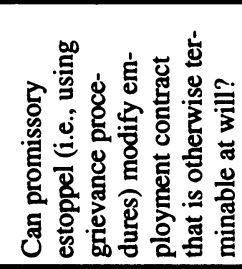 & 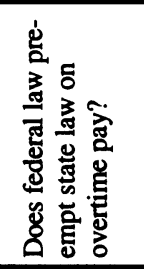 & 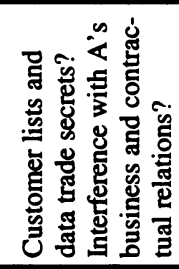 & 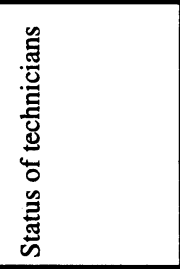 \\
\hline 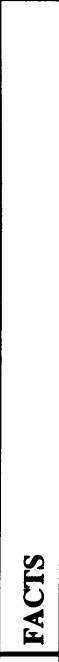 & 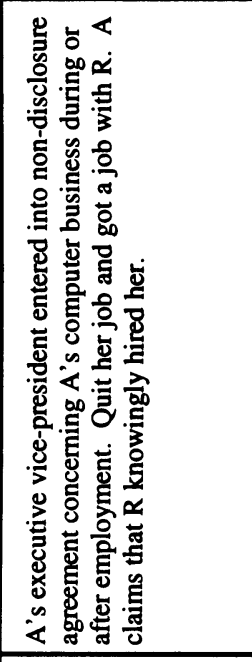 & 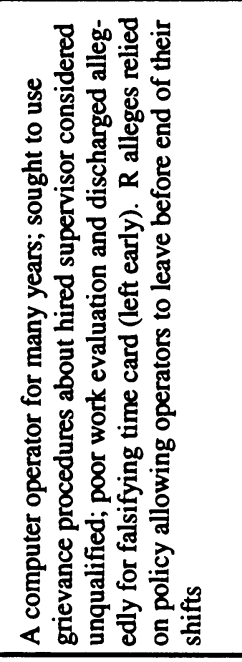 & 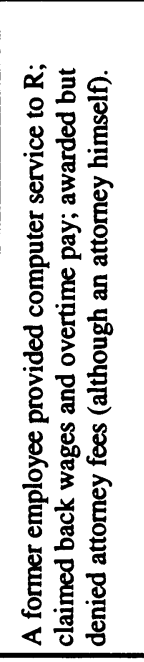 & 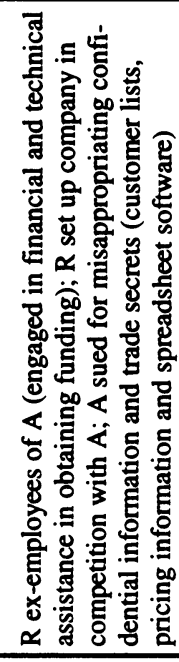 & 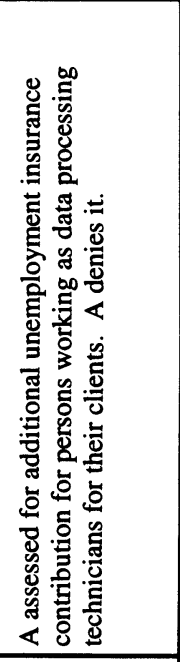 \\
\hline 岁 & 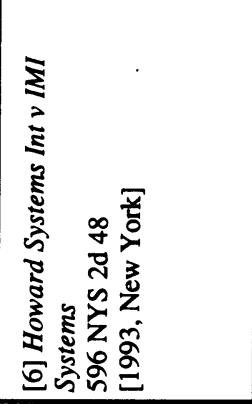 & 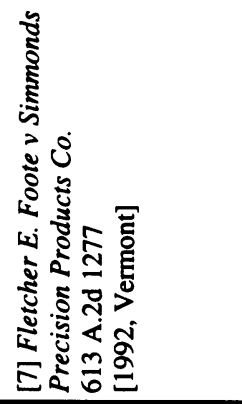 & 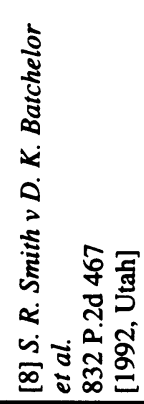 & 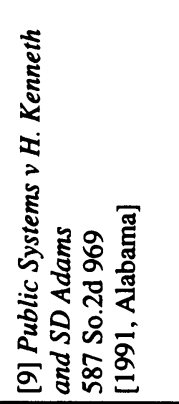 & 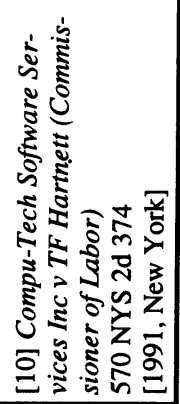 \\
\hline
\end{tabular}




\begin{tabular}{|c|c|c|c|c|c|}
\hline $\mathbf{z}$ & 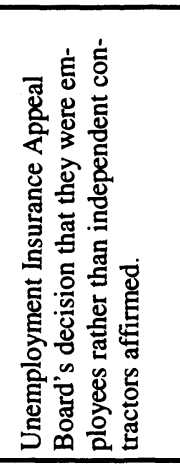 & 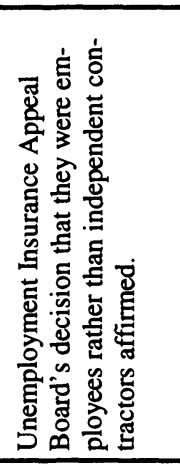 & 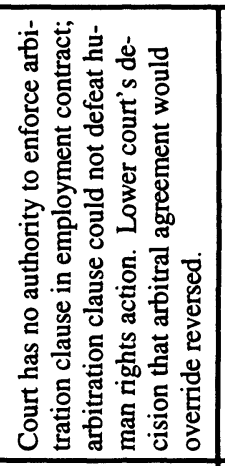 & 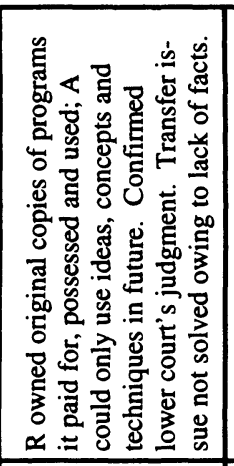 & 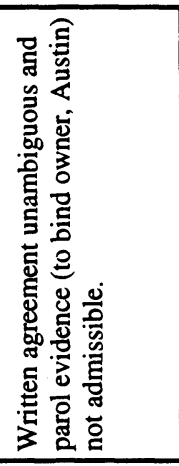 \\
\hline 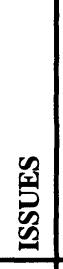 & 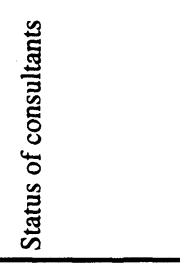 & 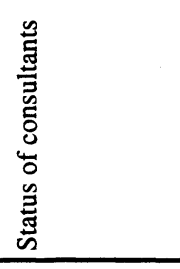 & 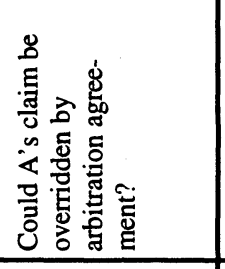 & 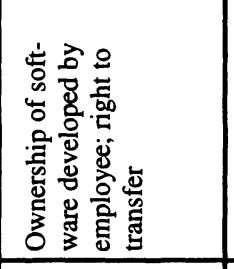 & 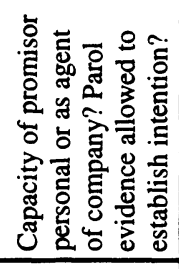 \\
\hline $\begin{array}{c}0 \\
\vdots \\
\vdots \\
\Sigma\end{array}$ & 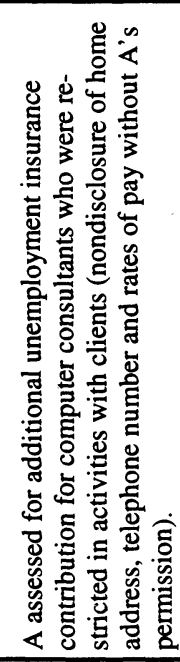 & 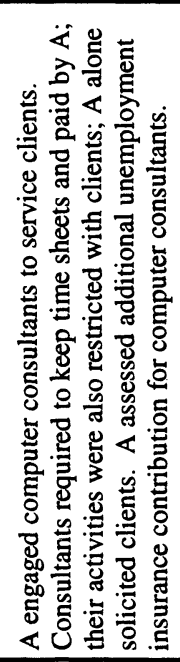 & 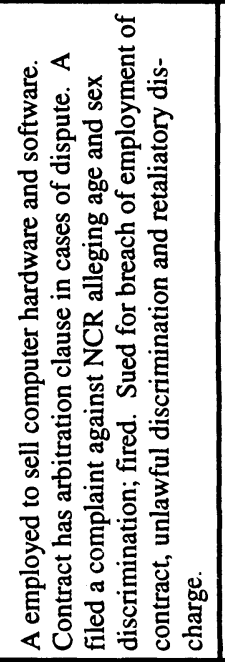 & 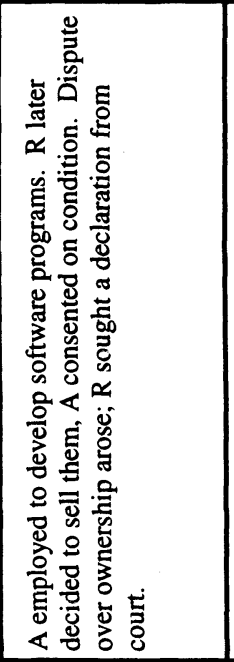 & 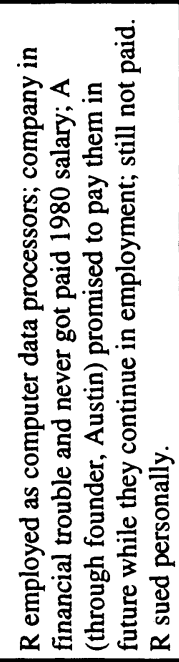 \\
\hline $\overrightarrow{2}$ & 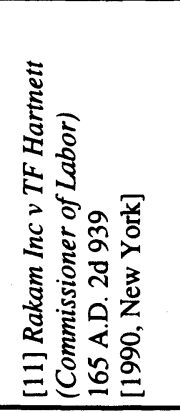 & 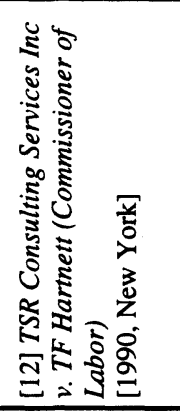 & 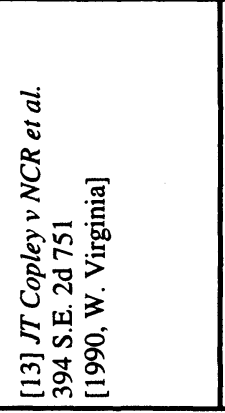 & 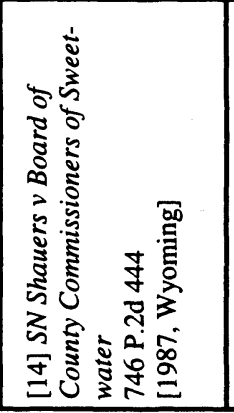 & 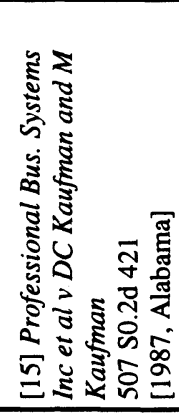 \\
\hline
\end{tabular}




\begin{tabular}{|c|c|c|c|c|c|c|}
\hline $\begin{array}{l}\text { 帘 } \\
\text { 窇 } \\
\text { 号 }\end{array}$ & 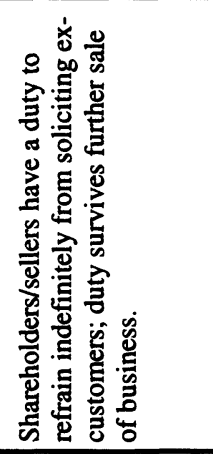 & 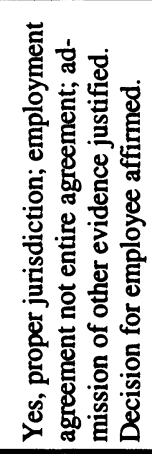 & 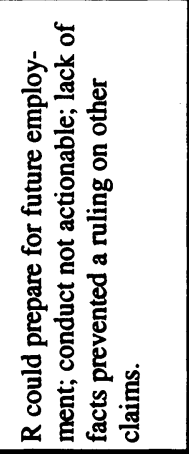 & 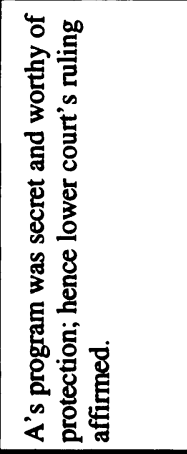 & 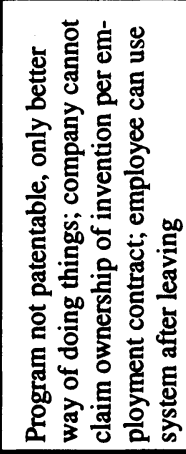 & 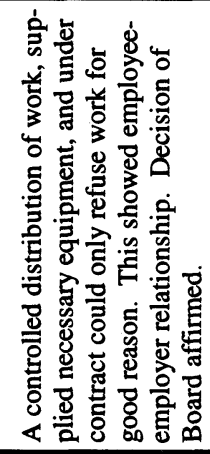 \\
\hline $\begin{array}{l}\text { 次 } \\
\text { 忽 } \\
\end{array}$ & 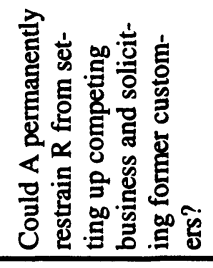 & 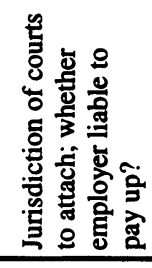 & 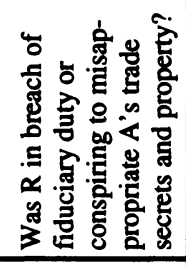 & 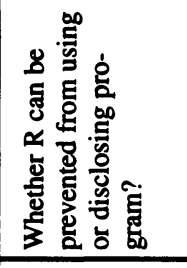 & 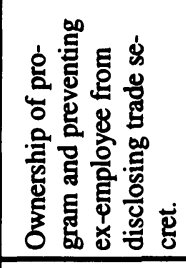 & 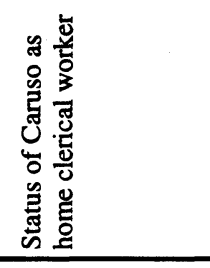 \\
\hline 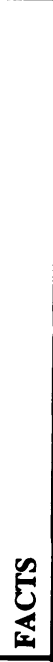 & 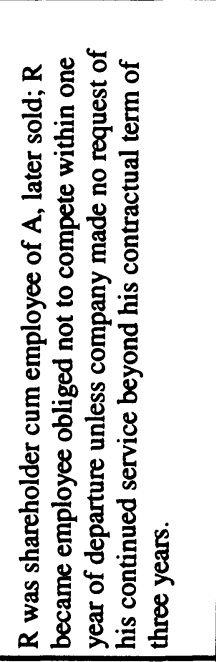 & 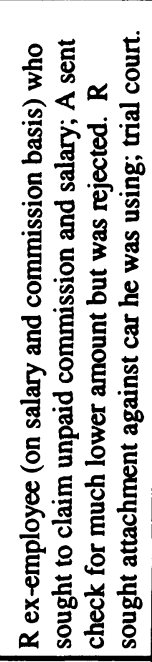 & 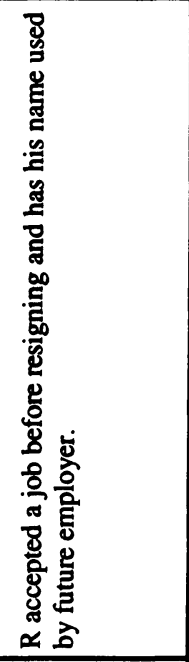 & 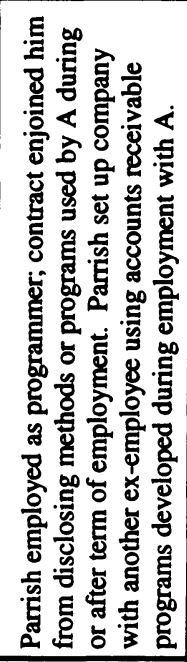 & 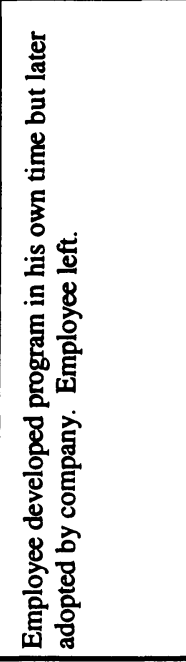 & 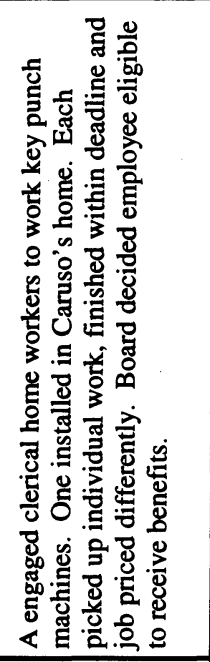 \\
\hline 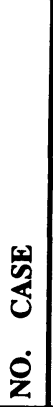 & 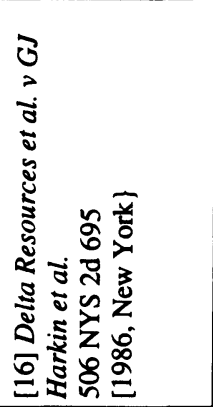 & 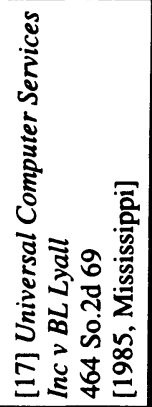 & 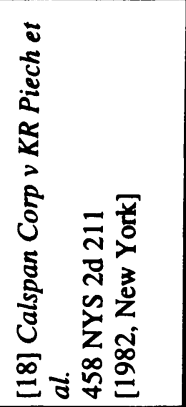 & 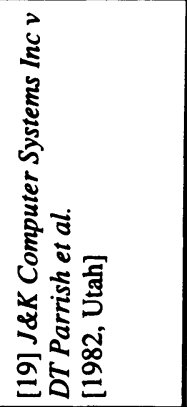 & 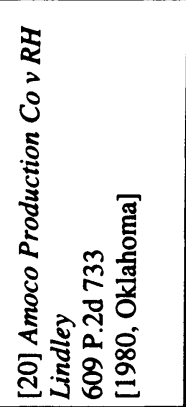 & 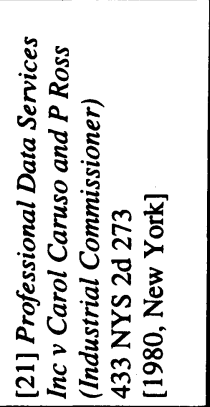 \\
\hline
\end{tabular}




\begin{tabular}{|c|c|c|c|c|}
\hline 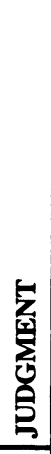 & 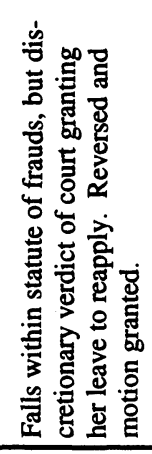 & 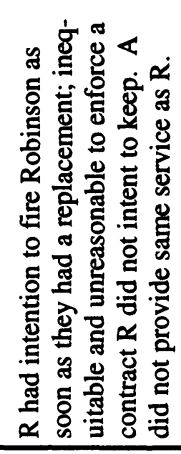 & 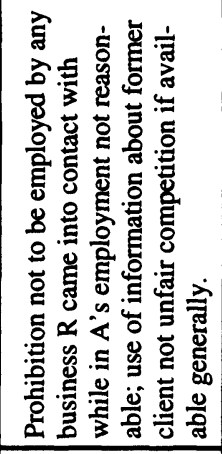 & 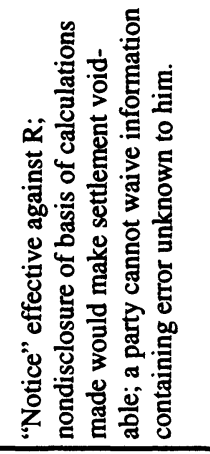 \\
\hline 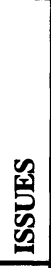 & 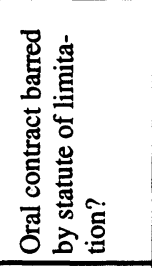 & 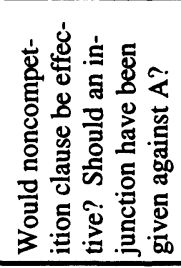 & 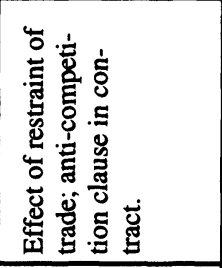 & 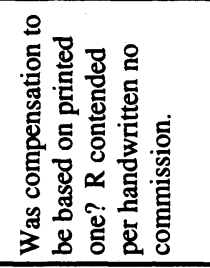 \\
\hline 岕 & 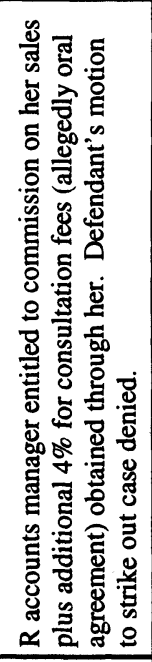 & 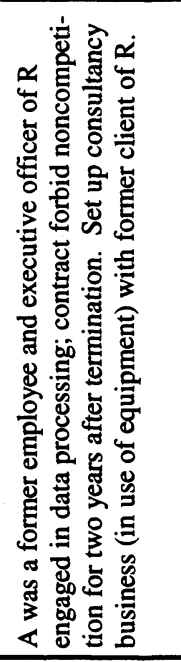 & 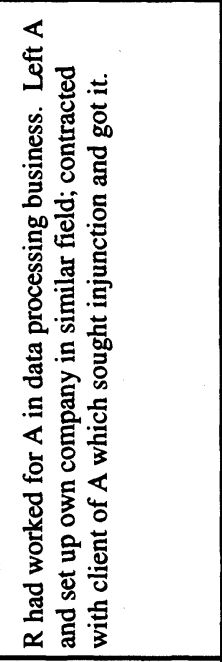 & 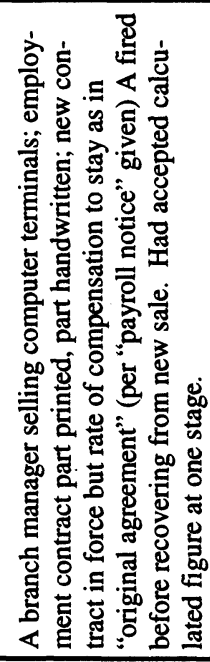 \\
\hline 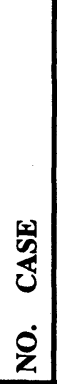 & 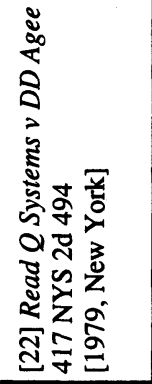 & 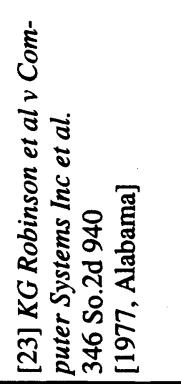 & 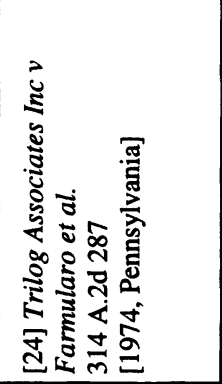 & 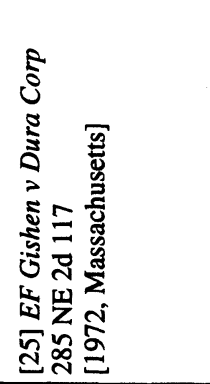 \\
\hline
\end{tabular}

